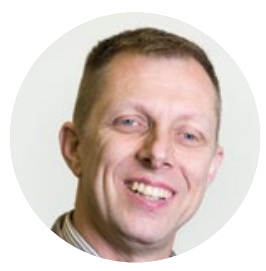

BART CUSVELLER

docent en onderzoeker zorgethiek, Hogeschool Viaa, Zwolle

\title{
Intenser en intensiever
}

Eigenlijk had ik me voorgenomen geen ethiekcolumn te schrijven naar aanleiding van de coronapandemie. Natuurlijk is de uitbraak van COVID-19 voor verpleegkundigen zeer belangrijk gebleken.

Daar wil ik niets aan afdoen. Het leek me alleen te makkelijk om nu ook maar iets over corona te zeggen. Bovendien, mijn belangrijkste aarzeling was of de ethische kwesties die door de epidemie aan de orde kwamen wel zo nieuw zijn. Het lijken me eerder uitvergrotingen van bestaande ethische kwesties.

Dan is het antwoord op de vraag hoe je daarmee om moet gaan ook niet echt nieuw, hooguit intenser en intensiever. Stel dat je werkgever niet voldoende materialen ter beschikking stelt om infectie van zorgpersoneel tegen te gaan. Wat zijn dan je rechten en plichten, ethisch gezien? Hetzelfde soort vraagstuk kan zich ook voordoen buiten de coronaperiode, bijvoorbeeld naar aanleiding van schaarste aan personeel. Of stel dat er een verdenking is op infectie bij een cliënt die alles letterlijk en figuurlijk niet meer zo goed kan bijbenen. Ga je je drukbezette tijd inzetten om zelf met de cliënt naar de teststraat te gaan? Stel je het uit? Hoe intens en intensief ook, dat is ook geen soort vraagstuk dat je nooit gehad zou hebben buiten de coronatijd.

Waarom dan toch een column naar aanleiding van corona? Welnu, het is goed te constateren dat ook verschillende vormen van ethisch overleg, moreel beraad en reflectie intenser en intensiever zijn geworden. Het is belangrijk dat deze respons vanuit verpleegkundigen en verpleegkundige zorg zelf komt. Alleen blijkt het overleg vaak nog georganiseerd te moeten worden. Laten we de situatie vóór zijn dat in een crisis blijkt dat we geen aandachtsvelder, teamcoach, scholing of commissie hebben geïmplementeerd. Als een epidemie ons iets leert, is het: voorkomen is beter dan genezen.

\section{GOLOFON}

\section{REDACTIE}

Marian Adriaansen (algemeen hoofdredacteur) Lianne van der Meer (redactiecoördinator)

Gerben Stolk (eindredacteur)

\section{EXTERNE REDACTIE}

Jacqueline van Dijk, Marijke van Hommerich, Nienke van der Voort

\section{REDACTIE ONDERZOEKSKATERN}

Anne Eskes (hoofdredacteur), Catharina van

Oostveen (hoofdredacteur), Guus Munten

\section{UITGEVER}

Yolanda Stil

REDACTIESECRETARIAAT

Bohn Stafleu van Loghum

Postbus 246, 3990 GA Houten

Marjoleine Gijsen, uitgeefassistent

tel. (030) 6383843

redactie.tvz@bsl.nl

\section{AUTEURSINSTRUCTIES}

Aanwijzingen voor auteurs zijn op te vragen via redactie: tvz@bsl.nl

\section{BASISONTWERP}

Miranda van Agthoven, Twin Media

\section{ILLUSTRATIE OMSLAG}

Monique Wijbrands

TvZ wordt uitgegeven onder auspiciën van de Stichting Publikaties voor Verpleegkundigen en Verzorgenden (SPVV) en is een uitgave van Bohn Stafleu van Loghum, onderdeel van Springer Media B.V.

\section{ABONNEMENTEN}

TVZ verschijnt zes keer per jaar.

Abonnementsprijs: (print + online toegang)

$€ 169$,-. Studenten ontvangen $50 \%$ korting.

Het abonnement kan elk gewenst moment ingaan en wordt automatisch verlengd tenzij twee

maanden voor de vervaldatum is opgezegd via het daarvoor bestemde formulier op

www.bsl.nl/klantenservice.

Als vakblad hanteren wij de opzegregels uit

het verbintenissenrecht. We gaan er vanuit dat $u$ het abonnement uit hoofde van uw beroep hebt afgesloten.

\section{ABONNEMENTENADMINISTRATIE}

Klantenservice Bohn Stafleu van Loghum, Postbus 246, 3990 GA Houten. Telefoon: (030) 6383736 Bij wijziging van de tenaamstelling en/of adres verzoeken wij u de adresdrager met de gewijzigde gegevens op te sturen naar de afdeling klantenservice of wijzigingen door te geven via het formulier op www.bsl.nl/klantenservice.

\section{ADVERTENTIES}

Cross Media Nederland, tel. (010) 7421020 gezondheidszorg@crossadvertising.nl

Aanleveren advertentiemateriaal,

tel. (030) 6383661 traffic@bsl.nl

VOORWAARDEN

Op leveringen en diensten zijn de bij de Kamer van Koophandel gedeponeerde algemene voorwaarden van Springer Media B.V. van toepassing, tevens raadpleegbaar op www.springermedia.nl. De voorwaarden worden op verzoek toegezonden. Het overnemen en vermenigvuldigen van artikelen en berichten uit dit tijdschrift is slechts geoorloofd met bronvermelding en met schriftelijke toestemming van de uitgever. Het verlenen van toestemming tot publicatie in deze uitgave houdt in dat de Standaardpublicatievoorwaarden van Springer Media B.V., gedeponeerd bij de Kamer van Koophandel te Utrecht onder dossiernummer $3210 / 635$, van toepassing zijn, tenzij schriftelijk anders is overeengekomen. De Standaardpublicatievoorwaarden voor tijdschriften zijn in te zien op www.bsl.nl/schrijven-bij-bohnstafleu-van-loghum/auteursinstructies of kunnen bij de uitgever worden opgevraagd.

www.bsl.nl, @ 2020, Bohn Stafleu van Loghum. ISSN 1380 - 3425

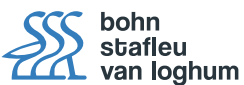

